\title{
The role of literature in instructed foreign language learning and teaching: An evidence-based survey
}

\author{
Amos Paran, Institute of Education, University of London, UK \\ a.paran@ioe.ac.uk
}

\begin{abstract}
The resurgence in the use of literature in language teaching has been accompanied by an increasing number of research articles in this area. Research (in a number of second languages) has looked at the type of interactions and the type of language that arise from classroom discussions about literature, as well as at the views of teachers and learners. Importantly, the reactions that learners have to incorporating literature in their language lessons are linked to the type of approach and type of task that are used in the classroom. The paper surveys the existing research, as well as evidence from practitioners about approaches that are used and the range of works and authors that are taught.
\end{abstract}

\footnotetext{
AMOS PARAN is the course leader of the MA TESOL by Distance Learning at the Institute of Education, University of London. His main research interests are reading in a foreign language, distance education, and literature in foreign language learning and teaching. He is the editor of Literature in Language Teaching and Learning (TESOL, 2006) and co-editor of Testing the Untestable in Language Learning (Multilingual Matters, forthcoming). He was the coordinator of the IATEFL Literature, Media and Cultural Studies Special Interest Group between 1996 and 2008.
} 
Introduction 
Literature has been the topic of a state-of-the-art paper in Language Teaching twice before, though the angle taken in each case was different. In 1988, Lott's survey, entitled Language and literature, was concerned mainly with examining literary language and the way linguistic thought was influencing (or not) literary criticism within the New Critics and structuralism. There was a short section on teaching materials, divided between materials for mother-tongue readers and materials for second language (L2) learners. Lott makes the point that in the latter type of material, the approach is normally through the topic, 'teaching becomes group guidance', and goes on to claim that 'the text itself ... is generally treated in a rather perfunctory way, and its distinctive nature as literature, and as a display of language put to special uses, seems often to be lost sight of' (Lott 1988: 9). In the section 'The way ahead', Lott discusses research as well - but in his case the search is on for an "extended, practical methodology for investigating language as it is used in literature' and the research is 'aimed at producing an operational model for the analysis of style' (ibid.). In contrast, Gilroy \& Parkinson's (1996) survey was entitled Teaching literature in a foreign language. It looked at developments in literary theory, reader response, and communicative language teaching, and then went on to examine materials for learners and teachers, focusing mainly on books (both specialist collections and general coursebooks) and to a large extent excluding articles. 
Both papers were - as state-of-the-art papers should be - very much of their period, reflecting the concerns of linguists and teachers at the time. But a number of points are noteworthy, and interestingly these are points concerning division and exclusion. The first important point is that neither paper looks at empirical research into literature in language teaching. It is true that there was far less research then than there is now (see also Carter 2007), but whatever research there was then is not always accorded a place. Secondly, both papers focus very much on English, with only a few references to other languages, reflecting the predominance of English as the main global foreign language, and the division between it and other foreign languages. Having said that, it is also important to note other divisions in this area. Kramsch \& Kramsch (2000) point out that, in general, foreign language teaching in the US has tended to remain enclosed within language boundaries, with separate professional organisations for different languages. Also in the US there is at university level the division between language teaching and learning and literature in general, a phenomenon which Kramsch \& Nolden (1994: 28) call 'the institutionalized dichotomy between literary studies and language training', as well as the division between the focus on language learning in the initial stages of an undergraduate degree, and literature learning in the later years of study (e.g. LymanHager 2000; Murti 1996). Burnett \& Fonder-Solano (2002), for example, have documented the misunderstandings between literature teachers and language teachers, including incidents of actual hostility (see also Byrnes \& Kord 2002; Fonder-Solano \& Burnett 2004). 
There is some tentative agreement that these divisions are beginning to be bridged. I have previously suggested (Paran 2006b) that in EFL, at last, there has been a move towards integrating language and literature, and Carter (2007: 10) suggests that at least some of the differences have begun eroding, and goes on to say that 'literature has begun to assume a higher profile in contexts of second language acquisition, a dimension absent from the research radar in $1986^{\prime}$. The present paper, as its title suggests, continues this trend, and moves the discussion from the definition of literature, from the language of literature, and from a focus on textbooks, to a focus on the emerging research in this area. It focuses on the research done in recent years on reading, learning, and teaching literature in a variety of foreign languages. The focus will be on the research that has appeared since Gilroy \& Parkinson's (1996) paper, although there are also references to previous papers as well, whenever relevant. 
However, there is still an obvious need to delimit the area of enquiry that this paper will deal with. Figure 1 presents the relationship between literature and language learning as the intersection of two axes. The horizontal axis refers to the extent to which any programme or lesson focuses on literature or on literary competence and its development. Thus, on the left hand side of this axis, where the learners are learning a second or a foreign language, there is little wish on the part of teachers to teach language per se; even where there is an engagement with language, this engagement serves a literary aim (e.g. understanding the linguistic choices made by the writer). The vertical axis represents the extent of engagement with language learning: at one end we have a focus on language learning, where the teacher focuses explicitly on language learning and activities are specifically designed to further this aim. At the other end of the axis, we have classes or courses where there is no explicit aim on language learning at all. 


\section{Language learning focus}

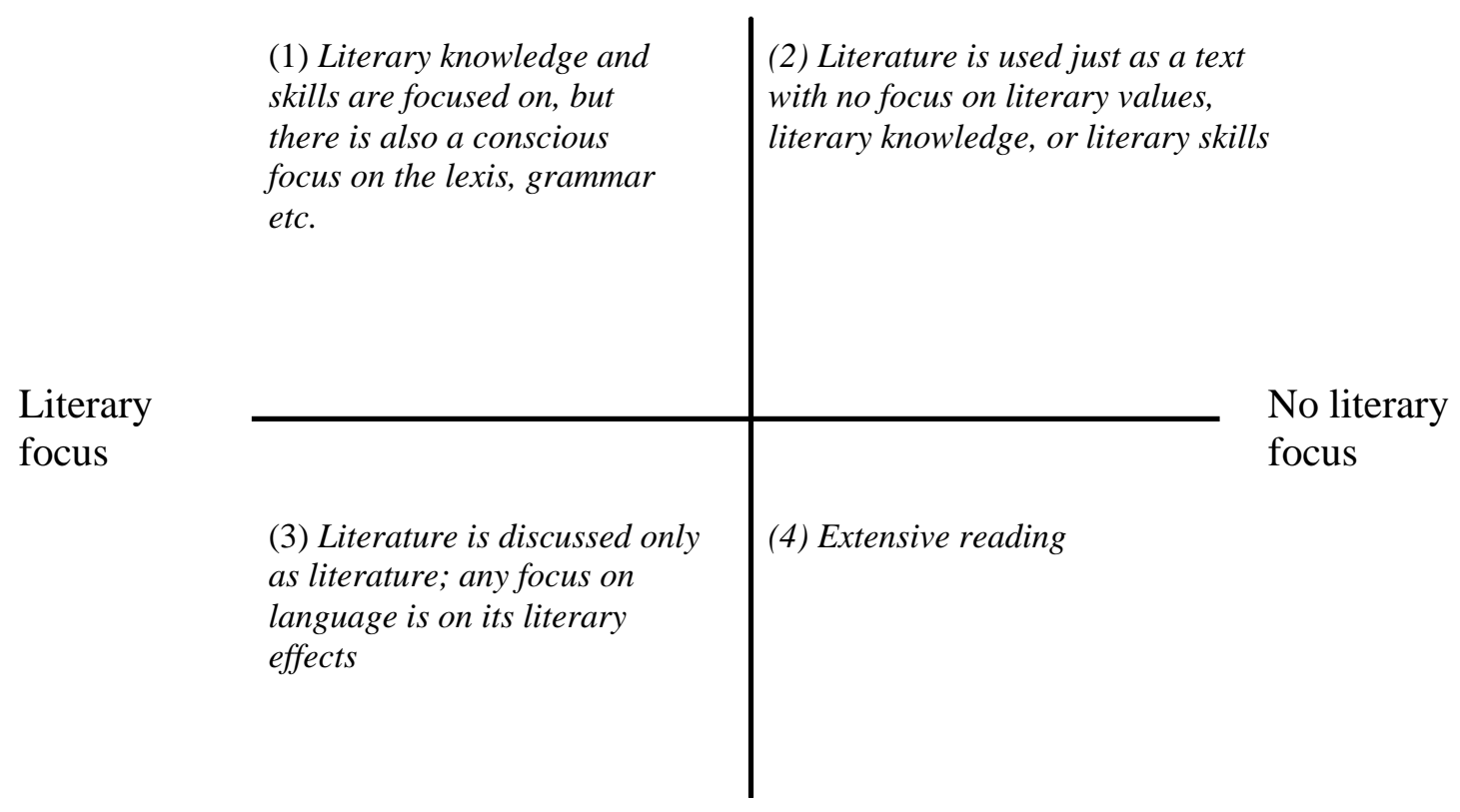

No language learning focus

Figure 1. The intersection of literature and language teaching 
The intersection of these two axes results, as Figure 1 shows, in four quadrants. Quadrant 1 represents a situation where both areas are focused on. Quadrant 2 shows a situation where no distinction is being made between what McRae (1991/2008) calls representational texts and referential texts, and representational texts are used in the classroom or in research settings without any focus on their literary qualities. Quadrant 3 exemplifies a situation where literature is discussed only as literature, and no overt focus is paid to language development: it is assumed that the learner has reached the linguistic level needed to discuss literature in the foreign language. This is the situation in many university courses around the world, and is indeed part of the deep divide discussed above. Finally, the fourth quadrant exemplifies extensive reading, where there is no focus on literary qualities of what is being read (and indeed, the material being read may well be non-fiction) and where, in its purest form, there is no language learning work either. In such cases there is often no reference at all to what is being read, and indeed, the reference may be to 'reading' or to 'books' rather than 'literature'. In between there is a whole gamut of approaches in which the literature-reading balance is calibrated differently. Figure 1 is, of course, a simplification: there are other important elements that can enter into a reciprocal relationship with literature in the language classroom. One, for example, is reading and the study of reading comprehension. The other is the issue of culture, cultural knowledge, and intercultural competence. A true picture of the situation would most likely resemble a web, with a large number of possible permutations of the interactions between the strands. In this paper, however, I will not refer to these areas, and my focus will be mainly on the areas between the two extremes I have described above, i.e. approaches where the focus is both on language and on literature, though with 
differing weight given to each in different situations and contexts.

2. The role of literature in language learning and teaching: Theory and research

2.1. Theoretical perspectives 
The shifting relationship between language learning and literature is still the subject of a great deal of debate. In a study looking at the way in which published articles in the Modern Language Journal have dealt with these issues, Kramsch \& Kramsch (2000) illustrate the movement from literature as part of an elitist study of foreign languages at the beginning of the $20^{\text {th }}$ century to a view of literature as an authentic source of language at the end of the century. Hall (2005), in a similar examination of the papers published in the ELT Journal, discerns a move from a suspicious attitude towards literature in the middle of the $20^{\text {th }}$ century, through attempts to incorporate it in communicative language teaching through humanistic techniques, reader response, and stylistics, highlighting a special ELT Journal issue in 1990 which focused on the shift from traditional methodologies to newer approaches. He then identifies the rise of a view which sees literature 'as potentially playing a role in facilitating the learner's access to this Englishusing culture' (Hall 2005: 55). 
One arena where the discussion has raged for some time is the use of literature in EAP courses in the USA. Belcher \& Hirvela (2000), Hirvela (2001a) and Vandrick (2003) provide an overview of the area, linking the controversy to debates in L1 teaching of writing in the US. Belcher \& Hirvela (2000) show how, initially, composition and literature tended to be taught by the same people at the time when the two areas emerged as subjects worthy of academic study, and the two subjects have diverged and converged over the years. In the L2 context, Belcher \& Hirvela (2000) trace the rise of ESP and the way in which the focus among L2 composition teachers on discourse communities and the language needed to participate in them, meant that literature and literary language were seen as unsuitable for inclusion in L2 teaching. However, they suggest that reading and writing only information-based texts may in fact prevent students from developing the 'array of rhetorical and linguistic resources' (Belcher \& Hirvela 2000: 29) that they need for their writing. Vandrick (2003) discusses the objections to the use of literature, such as the difficulties it might present, the lack of relevance of literature as preparation for academic writing genres, and the lack of motivation. 
An important discussion of the arguments for and against using literature in the L2 classroom is Edmondson (1997), whose overall position is that literature has nothing special to offer language teaching. Although the observations he makes at the beginning of his paper are drawn from a variety of contexts, the picture that Edmondson (1997) draws is one in which learners are exposed to the same type of literature teaching in L1 and L2, expecting a teacher centred approach in which the teacher's interpretation is all that counts, and overall not caring much for literature. He then presents a number of arguments either against the use of literature, or suggesting that literature does not have any advantage over other texts. Overall, he suggests that other curriculum subjects probably provide a better insight into culture than literature does; that literary elements and references in the language are not more important than other cultural references; that literature is not more motivating than other texts, and can sometimes be extremely demotivating, depending on the way the text is used; that there is no point examining at isolated cases of successful lessons (what he calls the 'Look at this!' argument); and that literature does not activate cognitive mechanisms in any way that is different from other texts. 
In Paran (2006b) I pointed out what I believe is the main fallacy of Edmondson's position and why it is important to debate these issues: namely, his view of language learning as focusing on language only, presenting what I call an isolationist position, whereby language learning is concerned with acquiring competence in the L2 and nothing more. Edmondson's view of the language learner chimes in with this, and is implicit in his phraseology: he talks about 'the business of language learning' (p. 42) and 'the business of achieving proficiency or general competence in an L2' (p. 45); the learners are 'educational consumers' and specific learners are 'the products of at least eight years school learning' (p. 43). This is similar to the trend that Shanahan (1997) identifies in FL teaching in the US, which he claims is a utilitarian business, which employs what he calls a 'reductively utilitarian logic' (1997: 165), where teaching a FL is justified mainly through its contribution to the learners' careers. 
This type of argumentation seems to be taking the learner as a person out of the equation: the focus is on the text, and on the learner as a language learning machine. In such a context, it may indeed be true that literary texts do not carry inherent characteristics making them suitable for language learning. The point is that literary texts are suitable because language is learned by human beings, and the interest and love of literature for its various qualities is a human characteristic, a common denominator in a way in which an interest in "history, geography, the economics or the architecture of other countries' (Edmondson 1997:46) is not. If we take as our starting point an understanding of the role of literature in daily life, the way in which narratives function in learning, the role of literature and narratives in education, and the language-literature link-all these are important in understanding that literature may have a place in L2 teaching more than the subjects mentioned by Edmondson in the quote above, or subjects such as 'philosophy, art, contemporary political issues, or other subjects on the humanist agenda' (Horowitz 1990:162). Language learning is not only about language - it is about learning as well; it is not only about training, but also about education. As Bredella points out "literary texts in the foreign language classroom are not only important for foreign language learning, but also provide it with significant educational goals' (Bredella 2000a: 380; see also Widdowson 1992: 77-85 for a discussion of the educational relevance of poetry). Shanahan (1997) presents an integrated view of this area, stressing that 'our fundamental goal as language professionals is to expand and enrich the lives of our students and the society in which they live' (Shanahan 1997: 171), and going on to explore the importance of the affective element of language learning and the importance of symbolic expression. 
More recent theorising has shifted away from a limited, isolating perspective in which the different areas of language learning are compartmentalised and teaching has a utilitarian, market-economy driven purpose, to more holistic perspectives which takes different aspects of the learner and the context of learning into account, looking at the whole person and the whole culture, in which literature is part of developing the whole person, and in which affective development and affective factors are taken into account. Kern \& Schultz (2005) view literature in a foreign language within a re-framing and redefining of literacy. They explore parallels between new concepts of literacy and 'the work of the literary specialist' (2005: 383), suggesting that the multiple-layered reading of texts characteristic of literary readings can, within a larger literacy framework, be of use for the teaching of this type of reading.

\subsection{Research perspectives}


Interestingly, both the supporters of the use of literature in language education (e.g. Shanahan 1997, Hanauer 2001) and its opponents (Edmondson 1997) agree that there is little research in this area. Indeed, Edmondson articulates an important plea: 'we need conceptual clarity regarding which role or roles foreign-language literature can or should play’ (1997: 44) in language teaching, and points out the paucity of empirical evidence for the claims being made regarding literature in language learning programmes. Since most of the writing in this area has been theoretical, the challenge for research is to validate these theoretical positions, and to support the claims that literature can contribute to language learning, that learners are motivated and interested in it, and that its study has something unique to contribute to language learning. 
The question, however, is how research can show this, what we classify as research, and what type of knowledge we accept as valid. Some of the research discussed in this paper, in particular in sections 3 and 5, is strongly rooted in the various analytical traditions of applied linguistics and takes a very clear empirical approach. However, an emphasis on this type of research can easily lead us to ignoring other types of knowledge, resulting in a situation where 'much of the interesting work done by teachers is not actually documented' (Rönnqvist \& Sell 1995: 52). Rather than dismiss this type of evidence (as Edmondson 1997 does in his discussion of the Look at this argument), we should realise that a consideration of the large number of papers of this type results in an understanding of what it is that teachers actually do in their classrooms, and of the issues that are at the forefront of the concerns of the teaching profession. It is important to remember that classroom interaction can be explored through the testimony of a practitioner reflecting on what they do in class, which can become extremely valuable (see Delanoy 1996 for the importance of reflective practice within this context). Such papers are even more noteworthy when we realise that they are often a description not of one experience, but of repeated experiences and indeed experimentation with literature in the classroom. Thus Cranston (2003) provides a large number of quick snapshots of different lessons in which she used poetry; Hess $(2003,2006)$ is in each case a description of a lesson used with different classes; Völz (2001) is an account of a number of years of using short fiction by the same writer; Diaz-Santos (2000) is based on three and a half years' experience of using technothrillers in the classroom. Indeed, it is such papers that perform the bulk of the task of documenting teachers' work, and through that, documenting what it is that is happening in language and literature classes. 
This paper therefore draws on work by both practitioners and academics. I start with a consideration of empirical research into the contribution of literature to L2 learning. I then move to a discussion of the views of learners and teachers, followed by a discussion of methodological issues that arise from the research. I then turn to a consideration of changes in syllabuses and curricula, as revealed in practitioner papers. I conclude with an overview and a discussion of future trends.

\section{Contribution of Literature to Language Learning}

3.1 The move to data based discussion 
Possibly the most important development in the field of literature in the language classroom in recent years is the way in which published work has added empirical exploration of the issues to theoretical discussions and practitioner research. Researchers have looked closely at the effect of different techniques and pedagogies (Isaac 2002; Scott \& Huntington 2007); the interaction between instructor and students and among students (Mantero 2002; Weist 2004); and the type and extent of output achieved (Boyd \& Maloof 2000; Donato \& Brooks 2004; Kim 2004; Scott \& Huntington 2007). Although the number of papers is small, this emerging area of enquiry is important because of the way these researchers focus on how learners as language learners are able to interact with the text, and on how literary texts influence classroom interaction, They also illustrate with data from the lessons themselves the learners' engagement with literature and the benefits that accrue to them.

\subsection{Research into cloze techniques}


An almost emblematic group of articles, spanning ten years and illustrating this move from theory through practitioner evidence to research is Mackay (1992), Weston (1996) and Isaac (2002). All three look at a language teaching technique which has regularly been adapted to a literary purpose: asking students either to fill in a gap in a text, or to choose between two or more alternatives to fill that gap (for illustrations of the technique in use see for example Carter \& Long 1987: 109124; Lazar 1994; Weston 1996). Mackay (1992) attacks this procedure, claiming that even native speakers find it very difficult to tackle successfully, and that for learners it presents a nearly impossible challenge. Weston (1996) attempts to refute Mackay's (1992) points, highlights flaws in his argument (mainly that the poem he picks as an illustration would normally be a very weak contender for a cloze), and goes on to provide examples of her own work with the technique. However, Weston's own examples (taken from Middlemarch) do not totally justify the procedure; she herself acknowledges that many of them present very difficult choices. To me, at least, it is not quite clear what is gained from the discussion of the various alternatives, and my feeling is that the same points could have been made by examining these alternatives without the challenge of deciding which was the one actually chosen. Weston (1996) is thus a good example of a case study presented in a way which fails to convince this reader, at least. (The same is true of Scott 2001, where this technique is presented in French, with very little attempt to explain why it worked. Badran 2007, on the other hand, is more successful because of the way in which the technique is used to sensitise learners to their own use of vocabulary and the effects achieved by deviant collocation.) 
Against this background, Isaac's (2002) contribution to the debate is important because it is based on an empirical body of data collected from learners: she prepared a rational deletion multiple choice cloze exercise, which the learners were required to do as homework, and the data analysed consists of the class discussion of the choices the learners had made at home. As Isaac (2002) demonstrates, her analysis does in fact vindicate the technique, and indicates 'that using gaps to highlight links in the semantic chains within an extract can provide learners with a way of grasping the cohesive structure of a text and can thus orient them towards its meaning' (Isaac 2002: 30). She also relates participation patterns to proficiency (more proficient learners focused more on context and its role), as well as links them tentatively to age and background (learners with a more traditional background in literature tended to participate less). Importantly, Isaac (2002) demonstrates that discussing the cloze exercise resulted in a more critical approach to the text, and also resulted in heightened affective engagement with it. She reinforces the view that the value of the technique is in the discussion that ensues from it, rather than in the activity on its own: she thus counteracts the suggestion that the technique is 'functional and mechanistic' (Benton 1996: 42). Most importantly, she counteracts Mackay's (1992) claim that the technique is intrinsically problematic much more successfully than Weston (1996).

3.3 Interaction in the literature and language classroom 
Other researchers have examined the type of talk and the type of interaction generated in the language and literature classroom and their contribution to L2 learning. (Boyd \& Maloof 2000; Mantero 2002; Donato \& Brooks 2004; Kim 2004; Weist 2004; Scott \& Huntington 2007). The findings illustrate the importance of two factors: the role of the teacher, and the role of the task.

Kim (2004) addressed three important questions that are at the front of the discussion in this paper: the evidence for affective involvement; the contribution of literature discussion to language development; and the students' perceptions of the use of literature. Kim (2004) observed a class of 9 students in a university in the US, interviewed the students, and recorded the classroom. She grouped the data into five categories (literal comprehension, personal connections, cross-cultural themes, interpretation and evaluation) and shows how the students negotiate the different categories simultaneously. She illustrates how literature circles provided opportunities for extended output, and led to a great deal of interaction, characterised by responsiveness, emotional engagement and authenticity. The interactions in her data are shown to be in stark contrast to the more limited IRE (Initiation-Response-Evaluation) patterns found in many language lessons (see also 3.4 below). The amount of interaction also emerges as important in Meskill \& Ranglova (2000), where the instructors in the study 'report that the amount and quality of student discourse as they undertook these activities was “astounding"' (p. 32). (However, this study describes a course which incorporated wideranging changes both in content and in method, and lasted a whole year, all of which make it difficult to disambiguate the causes of these effects). 
Other researchers have shown language improvement in classes using literature in contrast with classes that did not. Yang (2001) compared two classes in which part of the time was spent discussing shared readings with two classes which studied according to the previous study programme. The classes using literature outperformed the control groups. In another study, Yang (2002) used a pre-/post-test design, to examine the improvement of two elective classes in which literature was used. The two classes read the same science fiction novels, but the first class experienced traditional teacher centred lecturing on literature, resulting in a sharp drop in attendance. As a result, for the second class the researcher moved towards a student centred approach, with a mixture of group work, whole class discussion, short lectures and writing tasks, as well as filmed versions of the pieces. There was no improvement in the results of the first group, but a statistically significant improvement in the results of the second. Lao \& Krashen (2000) is an interesting study, since it illustrates the difficulty of deciding what counts as a 'literature class' and what does not. The study involved two groups of university students. One group was assigned a number of books to read, and the majority of class time was spent discussing the readings, whereas the other group underwent a standard study skills course. The experimental group showed significant gains in vocabulary and in reading speed, in contrast to the control group. However, whereas Yang (2001) and Kim (2004) provide detail that illustrates that their classes fall within Quadrant 1 of Figure 1, Lao \& Krashen (2000) provide detail that suggests that in fact their work would fit more comfortably into Quadrant 4, and is more akin to extensive reading. 
3.4 The role of the teacher 
The two studies by Yang discussed above illustrate the importance of the task and of the teacher in the literature/language classroom. This point is borne out by a number of studies which looked at teaching foreign languages in universities in the US, and which highlight the problems in this area. Mantero (2002) analysed the discourse in a literature and language class in a Spanish department in the US, focusing on what he calls 'text-centered talk'. Two frameworks were used to analyse the talk in the class. One was the Florida Taxonomy of Cognitive Behavior (Givens 1976 in Mantero 2002), which is based on the well-known Bloom (1956) taxonomy. The other was a framework specially devised for analysing classroom talk into different levels: utterance, dialogue, discourse, and progressive discourse (Mantero 2002: 443). The results of the analysis indicated that $60 \%$ of student responses were at the lowest of the taxonomy's seven categories, Knowledge of Specifics. Seventy-five percent of the talk was analysed at dialogue level, which at first looks encouraging until it becomes clear that many of the excerpts classified as dialogue are in fact dominated by teacher talk, and demonstrate a clear IRE pattern of interaction. The instructor seemed to believe that the text possessed an intrinsic meaning, and therefore many of the questions 'already have answers' (Mantero 2002: 451), i.e., they were display questions. Unsurprisingly, this led to the students talking not to each other, but to the teacher. In fact, although the course was billed as an introduction to Hispanic literature, its aims, once the data was analysed, turned out to be 'based on superficial readings for specific information in the hopes of building a vocabulary base that will assist in building oral proficiency' (Mantero 2002: 451). 
Similar findings arise from another study which used a variety of measures to analyse classroom talk in a Spanish department in a US university, looking this time at discussions of poetry (Donato \& Brooks 2004). Here, too, the findings indicate a preponderance of teacher talk ( $80 \%$ of the time) and, when students did talk, the same IRE pattern found by Mantero (2002). Donato \& Brooks (2004) also demonstrate how the pedagogical stance of the teacher (manifest in the use of IRE and, within the Initiation part, the nearly absolute dominance of display questions) led to an inhibition of discussion in the classroom, resulted in word or phrase length utterances, and prevented the learners from developing topics. Another indication of the limited nature of the language produced was the fact that $80 \%$ of the verbs used were in the present. The instructor did not take up opportunities to push the students and to recast their language, instead reinforcing their elliptical and undeveloped responses. In their discussion, Donato \& Brooks (2004) highlight the importance of literature instructors drawing on knowledge in language learning and teaching, and putting that knowledge into use in their classrooms: indeed, they talk of 'the catastrophic rift between language and literature instruction' (p. 196). 
In contrast to Donato \& Brooks (2004), who looked at an advanced literature class, Weist (2004) investigated an intermediate level Spanish course which focused on reading comprehension and incorporated literary texts for this purpose. Here she found that the teacher's aim was to enable the students to understand the texts, and for this purpose he moved from speaking only Spanish to using a great deal of English, including presenting some of the poems studied in English translations. Weist found that 'the course seemed to follow the traditional view of the instructor as the dispenser of knowledge... the instructor was viewed as the one who knew what was important about the texts, and the students often expressed a feeling of tremendous responsibility to develop the ability to interpret the texts like the instructor.' (Weist 2004: 214). Unsurprisingly, the instructor dominated classroom talk, speaking $90 \%$ of the time, though the students interviewed believed that they had taken part in a discussion. 
At yet another proficiency level, Scott \& Huntington (2007) investigated a beginners' class looking at a poem in French as a foreign language. Working within the framework set by the Standards for Foreign Language Learning in the $21^{\text {st }}$ Century, their focus was on the way in which the learners used what the Standards call the interpretive mode, which centres on 'the appropriate cultural interpretation of meanings that occur in written and spoken form' (Standards, p. 36, in Scott \& Huntington 2007: 4). Their focus was on comprehension, and they therefore asked the learners to discuss the poem in their L1, English. Two separate settings were investigated: small group discussion and whole class, teacher led discussion. The researchers found that in the small groups, focus on language and translation talk meant that there was very little interpretive talk about the poem; they suggest that it was the guidance of the teacher/moderator that enabled the teacher-moderated group to engage in interpretive talk. Interestingly, this chimes with Hanauer's (2007) investigation into learning literary interpretation in L1, where explicit modelling by a teacher had a stronger effect than group discussion. However, it is important to note that 'the act of establishing small groups does not by itself engender student discussion' (Boyd \& Maloof 2000: 167); neither Hanauer (2007) nor Scott \& Huntington (2007) seem to have incorporated an active task design into the programme, i.e., a design which ensures that group work is scaffolded and purposeful and that groups are kept 'on task'; as a result their conclusions about group work need to be interpreted with caution. 
In welcome contrast to the studies above, Boyd \& Maloof (2000) is an example of the way in which teacher involvement can provide a beneficial effect in the classroom. The class investigated was an elective dealing with American language and culture, taken by the participants in order to improve their English language skills. The main aim of the study was to investigate the ways in which ESL students in a class using literature made connections with other areas in their lives. The researchers took a wide interpretation of intertextuality, including in this any links students made to other literature that they had read, the other learners in the class, their own personal experiences, other cultures and languages, and universal qualities and concepts. Boyd \& Maloof (2000) attribute a great deal of the success of the class to the roles which the teacher assumed in the classroom, to the way in which she built on the intertextual links offered by the students, and to the way in which she supported student talk, reacted to it, and elicited further student utterances. The teacher's skill resulted in an important achievement, the high amount of student talk (68\%), in stark contrast to the studies presented above. One finding that does link these studies to Boyd \& Maloof (2000) is the importance of the links made: 'classroom talk was more likely to extend into discourse when students did not have to interpret the meaning of "Literature" and relied on their own experiences and expertise to talk about a cultural topic' (Mantero 2002: 449). 
To sum up, the papers mentioned above raise important issues regarding the dominance of the teacher and their role in language/literature classes. Kim (2004) ties these strands together when she suggests that 'the teacher should play a significant role in orchestrating and supporting both student interaction with the text and interaction with other students' (2004: 163). However, the papers above also raise the issue of which language is being used in class. The more the focus is on literature rather than on language development, the more teachers (and researchers) seem to allow the use of the L1 in the class. This phenomenon cannot be criticised in and of itself, but can only be assessed in relation to the aims of the class or of the study. Thus what is worrying for teachers about the Weist (2004) study is not the use of the L1, but the implicit belief of the students that they were in fact having a good discussion. In this context, the account by Tucker (2000) of using a poem in a beginners' French class is illuminating. Consciously choosing a poem that was much beyond the current linguistic level of the students, and consciously employing a teacher centred teaching technique that can only be termed idiosyncratic (presenting one line of the poem every day and discussing its meaning for 10 minutes in a mixture of English and French), and what must count as a dated overall task (memorising the poem), Tucker (2000) nevertheless created a meaningful learning experience which challenged and motivated her learners.

\subsection{The role of the task}

This point leads us to the next important issue, namely, the crucial role of the task in the language and literature classroom. This point, too, is now beginning to be investigated 
empirically. Thus Kim (2004) found that the topics raised in the different lessons that she observed 'largely depended on characteristics of the day's activities or assignments' (2004: 158). In Burnett \& Fonder-Solano (2002) the course reader was perceived as unsatisfactory 'due to its lack of pedagogical help' (2002: 96), and was therefore changed.

Beatty \& Nunan (2004) compared a behaviorist and a constructivist design for learner dyads who were working with a CD ROM, focusing on Mary Shelley's Frankenstein. The researchers hypothesised that a constructivist, open-ended interface would lead to more collaboration and a more exploration-oriented experience on the part of the students. However, this hypothesis was not confirmed, and in fact there was evidence in the data that the behaviorist interface led to more collaboration. Beatty \& Nunan (2004) conclude that 'the greater degree of scaffolding provided by the behaviorist interface gave subjects using this interface more confidence to wander away from the tasks and explore the materials in greater detail.' (2004:179). Overall, the studies presented in this section illustrate how 'local classroom conditions can encourage or restrict' the potential that literature classroom has for generating communication in the language classroom (Boyd \& Maloof 2000: 166). 
3.6 The role of the reader 
The studies discussed in the previous section looked at what learners do, but always within the context of a classroom, with a strong element of teacher intervention. A further aspect of the move towards an empirical approach to this area has been research into the role of the reader and what the reader does as an individual when reading literature. Following from the theoretical arguments set out in Hanauer (1997), namely, that poetry is particularly suited for use in L2 learning because understanding poetry is inextricably linked to considering form, Hanauer (2001) asked learner dyads to read a poem, and try to understand it. It might be argued that a better way of accessing what learners do would have been an introspective or think-aloud task; however, Hanauer (2001) suggests that this would have raised problems of cognitive overload. Overall, the study illustrated how the task forced the participants in the study to stretch their knowledge and 'extend their understanding of the potential range of uses and meanings of an existing linguistic structure' (Hanauer 2001: 319). The analysis of the learners' discussion revealed that the majority of utterances concerned language, rather than literary form. In an analysis of the utterances into different categories, nearly $60 \%$ of utterances belonged to two categories: noticing, and interpretive hypothesis. The categories were then grouped into functions, with the most frequent function being constructing a local interpretation (40\%), followed by the function of developing a local interpretation (21\%) and collecting data (18\%). Mattix (2002) suggests that this is an artefact of the instructions, and argues that what is missing from the study is an affective and aesthetic element. To some extent, Hanauer (2001) deals with this issue by noting the way in which the learners directed their attention to 
language rather than literary issues, and uses it to pre-empt potential criticism of the use of poetry in the language classroom (namely that the learners might not be sufficiently focused on language). What Mattix (2002) notes, however, may not just be the artefact of the instructions, but an indication that before they can deal with the aesthetic elements of a poem, L2 learners need to reach an understanding of the language and the meaning of the poem.

In contrast to Hanauer (2001), who focuses on the process of making meaning when confronted with a literary text, Fecteau (1999) focuses on the product, i.e. whether learners reading a literary text achieve an understanding of its literary qualities. This is an interesting study because it attempted to combine the concerns of reading teachers with those of literature teachers, and compared reading in L1 and in L2. Of interest here are the four multiple choice questions in which Fecteau sought to establish whether the learners had correctly identified the narrator, the tone, the themes, and the author's aim. However, even those participants who read the texts in L1 did not do particularly well, and Fecteau was forced to conclude that her participants' ability 'to identify literary features in a specific text was, at best, inconsistent' (Fecteau 1999: 488). However, the product orientation of the study means that it cannot really shed light on the way the students processed meaning, and the small number of questions raises important questions of validity and reliability.

\section{Views of teachers and learners}


4.1 What learners think

Findings in this area are still quite rare, and it is extremely difficult to make any generalisations, considering the high variation in terms of study focus and participant profile, the lack of similarity between the groups studied, and, indeed the language studied. In some studies literature is examined under the heading 'cultural readings' (Harlow \& Muyskens 1994) whereas in other cases literature is clearly separated from ‘cultural knowledge' (e.g. Martin \& Laurie 1993).

Generally speaking, two types of research can be discerned in this context. One is large scale surveys which look at the needs and wants of language learners and at the place of literature in this context. The other is specific feedback on courses that included literary texts.

\subsubsection{Learner Surveys}


Different surveys have indicated the scepticism that learners have towards literature.

Martin \& Laurie (1993) investigated the goals of students studying French in an Australian university, as well as their views of learning literature. It is interesting to note that Martin \& Laurie (1993) found that their respondents 'saw a direct, almost mechanistic correspondence between the topic or activity and the skill it most clearly exercised. ... they did not see much transfer between skills areas, but rather tended to compartmentalize their learning in each area' (Martin \& Laurie 1993: 192). Their respondents believed that literature study would contribute to their reading skills, but little to any of the other skills. This may well be connected to the way literature was taught. In follow up interviews, the researchers found that "what seemed to put the anti-literature students off was the obligation to study literature, as distinct from reading it for enjoyment or personal development. Literature did not interest them as part of a French course, not only because of scepticism about its contribution to the four skills, but because they did not feel competent to deal with it in a way which would oblige them to discuss it in a public forum' (Martin \& Laurie 1993: 201). Interestingly, the interviewees also commented on the differences between the ways in which textbooks present cultural knowledge, in pre-digested form, and the way in which cultural understanding is achieved through reading literature. Finally, the researchers concluded that there were important issues of methodology here, and simply going through the techniques of literary analysis with their learners would turn them off literature; they call for a more student centred methodology which values the contribution of the learner to the discussion of literature. 
In another large scale survey, Harlow \& Muyskens (1994) investigated the immediate language learning goals of nearly 1400 intermediate level learners of French and Spanish in twelve US universities. Reading literature ranked $11^{\text {th }}$ on a list of 14 goals (compared with reading non-literary texts, which ranked $7^{\text {th }}$ ). When asked to rank the importance of different activities in helping them to achieve these goals, the students ranked reading in $7^{\text {th }}$ place, and cultural readings $13^{\text {th }}$ (this result is, however, partly an artefact of the research methodology, since the survey explicitly asked the students to link their answer to this question to their language learning goals). The researchers suggest that the low ranking of cultural readings both as goal and as activity raises the issue of how to prepare students for later levels of study and for the in-depth cultural analysis typically found in advanced courses' (Harlow \& Muyskens 1994: 151), thus highlighting the disjunction between language and literature teaching in FL language departments. Although the findings are of interest, one potential problem with this study is that reading literature was presented as one element among more general ones such as vocabulary, grammar, speaking, listening, etc. It seems logical to assume that a more specialised goal would rank lower than more general ones. In addition, it is important to note that the means in this study were not in fact substantially different from each other, and that thirteen of the fourteen goals achieved a mean above 3 on a 1-5 Likert scale. 
Studies looking at EFL students present similar results. Qiping \& Shubo (2002), in an impassioned plea for raising the role of literature in English departments in China, report on a study that indicated that ' 34 percent of the teachers of English literature were found by the students to conduct "boring" classes, mainly because the teaching tended to be in the form of a monologue rather than a dialogue' (p. 321). In Hungary, Kormos, Kontra \& Csölle (2002) found that students on English teacher training programmes were not reading a great deal of fiction; however, it is important to note that this still ranked first among the uses of English in the private domain. Among past graduates, this went down to joint $6^{\text {th }}$ place, but the change in frequency was minimal. Overall, Kormos et al. (2002) found that their students read less frequently in English than they expected. One large scale survey which presents very different results is Davis, Carbón Correll, Kline \& Hsieh (1992), who surveyed 175 students of French and Spanish in two universities in the US. Their respondents found their literature studies rewarding, and nearly three quarters agreed or agreed strongly that undergraduate students in language departments should be encouraged to take literature courses. However, these findings should be considered with caution, since all the respondents were taking literature courses in foreign language departments.

4.1.2 Student response to courses incorporating literature 
Markedly different results are exhibited in another strand in the research, one which examines the reactions of students to specific courses where literature was used. Unlike the surveys, the results in most of these studies are positive, though one could argue that this is not surprising, as these studies reflect cases where the students are often self-selecting, and the teacher is particularly enthusiastic about using literature. However, the picture that emerges is more complex than this. One interesting study is Hirvela (2001b), which examined the reactions of learners on an EAP writing course to texts of different types. Although this was a small scale study (38 participants reading one text in each of four genres), it is noteworthy that the learners viewed the literary and semi literary (essay) texts as the most enjoyable to read, the most interesting to read, and the most enjoyable to write about, though these two texts were also found to be the most difficult to read and the most difficult to write about. The literary and semi-literary texts also came first when learners were asked which text they would recommend for future use on similar courses. Interestingly, the academic and newspaper texts were seen as more helpful than the two other genres, but the differences here were very small. Hirvela (2001b) suggests that his findings support the advisability of using different types of texts over a student's academic career. This is very much in line with the thinking behind the course constructed by Kelly \& Krishnan (1995), though their students seemed to find engagement in literature more problematic. In a later study, Hirvela (2005) investigated the reaction of two groups of students to working with Graham Greene's The Tenth Man. Overall, the students approved of using literature in their studies, although their support was more qualified than 
that of the students in the earlier study. Hirvela (2005) suggests that for these learners, literature should be seen as one possible component of a course, and that its use should have a clearly defined academic purpose.

Diaz-Santos (2000) reaches similar conclusions. He conducted a survey with three ESP classes who had read technothrillers. All three classes found the course valuable, interesting and informative, and students felt that they had learned a great deal. Like Hirvela (2001b), Diaz-Santos suggests that this approach can be combined with other approach to ESP.

Yang (2001), using questionnaires and interviews, found strong support for the use of literature circles in a class of adult learners. The interviews suggested that the students felt that the discussions of the novel they were reading were "more "substantial" than simply answering grammar questions' (Yang 2001: 459). In the interviews, some of the students pointed out the similarities between discussing novels and their plots and narrating events in conversation outside the classroom. In a later study, Yang (2002) interviewed the learners in the two classes which experienced a different approach to literature. Students in the class where literature was taught in a more student centred way showed a much more positive attitude to the literature used in the class. Importantly, though the students did not think the actual subject matter of the literature class would be of use to them, they realised that their language had developed and recognised the importance of that. They also acknowledged developments in their critical attitude towards their reading. 
Like Yang (2001), Kim (2004) interviewed the students in the literature circles that she observed, and found an overall positive response indicating involvement and enthusiasm. She also found that the students believed that the discussion of their reading contributed to comprehension, once again indicating the importance of the activities associated with using literary works.

Meskill \& Ranglova (2000) found that their students responded favourably to a revised curriculum incorporating technology and literature in Bulgaria. However, the findings here need to be interpreted with caution (see section 3.3 above). Yeh (2005) found that a class of 22 students on an advanced speaking and listening course reacted favourably to the use of poetry, and that $95.5 \%$ of the class believed the activity was beneficial to their language skills.

Schmidt (2004) explored the views of L2 learners in German secondary schools to studying Shakespeare in their English lessons. Her main finding was that most students accepted Shakespeare as an important part of their compulsory studies and thought he should be on the curriculum, but this was not accompanied by an actual interest in reading and studying Shakespeare. A cluster analysis of the responses of more than 400 learners in 28 different courses revealed a strong connection between the teaching approach that the learners had been exposed to (as revealed by their own answers) and their interest in the subject. Schmidt suggests that "pupils seem to profit most from a balanced combination of both learner-centred and text-centred approaches' (2004:211). 
Overall, then, the research indicates that learners who have been exposed to positive experiences with literature, and who are given the opportunity to read literature and respond to it, both benefit linguistically and enjoy the experience. What is particularly interesting about some studies (e.g. Hirvela 2001b, 2005; Yang 2001, 2002), is the way in which the students are voicing the same arguments in favour of using literature that methodologists voice - that it is enjoyable, that is deals with substantial and non-trivial topics, etc. This is true not only of language majors, but also of students at all levels who are majoring in other subjects. Thus Liaw (2001) reports on the positive response of students in the College of Management in her institution to using short stories in a language class; the students felt that they had gained from it both linguistically and affectively; Minkoff (2006) reports on a literature elective in a business school in France which has run for several years. Tutas (2006), working within Rosenblatt's (1978) transactional theory of reading, also shows how it is possible to work with students who have previously experienced a teacher-dominated, efferent mode of reading literature and to move them towards an aesthetic response. Both Liaw (2001) and Tutas (2006) used journals in their work with students, and this may be an important procedure for this type of work, reinforcing the points on the importance of task design made elsewhere in this paper. What may well be a determining factor is the way in which the learners are exposed to literature.

\subsection{What teachers think}


One important point here is that FL teachers normally receive no training in using literary texts in the classroom (Hirvela 1989; Belcher \& Hirvela 2000) Methodology handbooks often have no mention of literature (e.g. Hedge 2000; Richards \& Renandya 2002), though Ur (1996), Celce-Murcia (2001) and Carter \& Nunan (2000) are exceptions, and Harmer (2001) includes literary texts in the section on reading. Kramsch (1993) suggests that non-native teachers may experience 'feelings of inadequacy .... when interpreting foreign literary texts' (1993: 137), and that their own training in literary analysis may prevent them from using reader-response techniques in the classroom. McRae (1996: 228), talking about literature teaching in general, suggests that 'the dominant paradigm in literature teaching world-wide is still teacher-based input', and Bernhardt (2002) has suggested that many readers of literature in L2 classrooms rely on the secondary literature for their views of the text. Subsequent research in the field bears out these observations (e.g. Mantero 2002; Donato \& Brooks 2004; Weist 2004; see section 3 above). These points are related: the lack of training then means that if teachers want to use literature later on in their teaching, they do not have the methodological wherewithal to do so, cannot engage in an informed debate in this area, and fall back on teaching the way they were taught, perpetuating teachercentred approaches. The absence of training also sends out a powerful message that literature is not something that is worth dealing with. 
The Harlow \& Muyskens (1994) study discussed above included a survey of 59 French and Spanish instructors. Like their students, these teachers ranked literature $11^{\text {th }}$ on the scale of 14 goals for language instruction; in terms of activities, they ranked cultural readings $10^{\text {th }}$ on the list of 19 activities, which was higher than their students. (Note, however, that the reservations expressed above apply to the teacher survey as well.)

One important point in this context is the ability of teachers to understand their own methodological needs. Weist (2004), for example, found that the teacher that she observed had never taken a methodology course, but did not perceive this as a problem, although the classes she observed were 'plagued by misconceptions and unrealistic expectations of both students and instructors' (Weist 2004: 218-219). In another study that examined teachers's attitudes, Gilroy (1995) looked at views of teachers in a convenience sample of teachers in her institution. Gilroy's informants did use literature in the classroom, mainly as 'an added extra' (p. 8), and viewed it as a resource like any other. They did not use it regularly, and did not feel the need for training in this area. 
In stark contrast to the teacher in Weist (2004) is the study by Burnett \& FonderSolano (2002; see also Fonder-Solano \& Burnett 2004) in which they examine their routes to teaching literature, their beliefs about it and their own teaching practices and approaches to teaching literature. They document the split between literature and language in university foreign language departments. Interestingly, one of the two authors, Burnett, felt a great lack of confidence in her ability to teach literature, rooted mainly in her negative experiences as a student of literature herself. In both papers the authors explore the differences in training that they received as well as their perceptions concerning what a course at this level should consist of. Another study of a teacher setting out to establish a literature elective with no training in literature or literature teaching is Minkoff (2006), who documents his personal exploration of issues of literature teaching as he prepared the course.

The new focus on literature, however, means that this situation is changing, and we now have descriptions of courses which aim to train teachers in this area (e.g. Martin 2006; McNicholls 2006; Rosenkjar 2006). It is therefore possible that the generation of teachers being trained now are less worried about their ability to use (or teach) literature in L2 settings.

\section{Extending approaches and methodologies}


The previous sections have emphasised the importance of the teaching approach and the tasks used by teachers. This section looks at the attempts to adjust the type of teaching that occurs in the language and literature classroom, and at the documentation, but practitioners, of their experimentation with different types of teaching and different types of lessons.

\subsection{Reader response}


One approach adopted by a large number of teachers in different contexts is the readerresponse approach, which within foreign language teaching has often been based on the work of Rosenblatt (e.g 1978). Ali (1993) describes the five features of the way she adopted this approach in the Malaysian context: invoking a schema for comprehension; sharing the initial response; repeated reflections in a reading diary; teacher intervention through group tasks, and project work. Liaw (2001) implemented a similar programme, which included schema activation, discussions, role plays and dramatisations, with a very strong stress on journal writing - learners were required to write in their journals and handed them in for grading. Tutas (2006) describes the move from a teacher-dominated study of literature to a transactional approach; importantly, she shows the development in the language used to write about literature in a class that was taught along reader response lines. Many of the other studies discussed in other sections in this paper incorporate elements of reader response and the activities associated with the approach, such as role play, group discussions, reader's journals and projects.

\subsection{Focusing on the Task}

A number of papers address the issue of task from a classroom perspective. Durant (1996) is a particularly detailed discussion of these issues. He suggests a major methodological principle for designing tasks for the language and literature classroom, namely, that the role of the teacher is to construct group activities that will provide the learners with the scaffolding needed to reach an interpretation. Clearly, this type of 
thinking presents a methodological bridge between the teacher dominated classrooms described in the research discussed above, and the communicative language classroom. Paran (1999) suggests that some group activities mirror Wilkins' (1976) distinction between analytic and synthetic approaches: rather than being presented with an analysis of the work (as would happen in a teacher centred approach), here learners need to construct their own analysis of the poem, making this an analytic approach to learning. Baurain (2007) describes a way of dealing with literary tasks in large classes (by which he means a class of about 100 students). This involved what he calls a 'multitasking structure', which consisted of six task categories. Each group was assigned one of the tasks, and worked on it for about $60 \%$ of class time, after which groups presented their work to other groups.

5.3 Literature and technology 
The concept of technology, or, more exactly, what would be considered as 'new' technologies, is a fluid one. Technologies which were once considered new and revolutionary are now incorporated into teaching almost as a matter of course. Film and video, for example, are part and parcel of any L2 course which incorporates literature, and this is well documented in a large number of papers. Rönnqvist \& Sell (1995) document the use of video in conjunction with YAL; Delanoy (1996) discusses a teaching unit which focused on poems that were taken from the film Dead Poets Society, in itself a film about L1 literature teaching. Veteto-Conrad (1997) discusses the use of feature films and documentaries in various formats. Lao \& Krashen (2000) showed their students films of most of the books that the students read. A recent example is Yeh (2005), who describes the way in which powerpoint and on-line video were incorporated into a poetry lesson, as well as in student assignments after the lesson. 
However, it is probably safe to say that the word 'technology' as currently used will probably refer to electronic media and electronic means of communication. In its simplest manifestations, teachers have used email to arrange written discussions between learners in different countries reading the same piece of literature (Jackstädt \& Müller-Hartmann 2001) or between language learning classes and their L1 counterparts in another country (Meskill \& Ranglova 2000). Gombocz (2001) describes how email is used to circulate questions prior to a session to students at remote locations on a distance programme. Hirvela (2007) takes this further, using asynchronous computer-mediated communication to enable his ESL learners to correspond with the author of the novel they were reading. Though the students were grateful for this opportunity, and some of them entered a meaningful dialogue with him, the group as a whole did not participate or write as much as had been hoped. Hirvela (2007:53) concludes that this study thus 'complicates rather than clarifies our understanding of the use of computers in composition instruction'. 
The use of the web and its resources is now almost commonplace, with teachers either requiring that their students access the internet directly, or downloading and arranging materials for the students (e.g. Beatty \& Nunan 2000, Schulte 2006; see Gombocz 2001 for a list of websites for German literature; see Browner, Pulsford \& Sears 2000 for websites for literature in English). Other quite basic procedures are using the internet and the web to access additional resources (King 2000) or for project work (Schaumann 2001) or using chat software for role play, which in this case might mean assuming the role of characters from literary works, or of writers (Fraser 1999). Another technological advance is corpora and concordancing; Louw (1997) shows how L2 learners who may mistrust their intuitions regarding connotations of words they encounter in literary texts can use corpora to check and verify their thoughts.

Where courses incorporate technology, the design of the interface and of the tasks that are provided is of the utmost importance; Gombocz (2001) suggests that 'the key to the success of the telecourse has been the translation of reliable classroom practices to the virtual environment, along with an extended use of electronic and audio-visual educational resources' (Gombocz 2001: 64). The study by Beatty \& Nunan (2004) discussed in section 3.5 above is an example of the importance of task design in this field.

Schulte (2006) is a good example of how a fully elaborated procedure, the Webquest (www.webquest.org) can contribute to language learning through an engagement with literature. This is also a good example of the way in which task designers consider different technological solutions to the issues that arise - in this case, the decision to provide the learners with the material they need on a CD ROM, rather than ask them to go on to the web and find the information there. 
More ambitiously, Meskill \& Ranglova (2000) describe the way literature and technology were integrated in a new curriculum for university students in Bulgaria. The approach is characterised by three principles: the use of literature (in this case, short stories) as content, collaboration as a way of learning, and technology as the mediating tool through which the collaboration is organised. Importantly, the writers start the discussion of technology with low-level technology - integration of audiotaped selections from the short stories into the programme; use of concordancing and corpora to research linguistic issues that arise from the literary selections; extensive use of word processing; email collaboration with a partner group in the US. The language gains of a group studying the revised curriculum and a group studying the traditional curriculum were compared. The revised curriculum group showed mean gains that were significantly higher than those of the experimental group on three out of five measures (reading and vocabulary, writing, and grammar).

Overall, traditional classroom and homework activities are increasingly being moved over to technological media. As more and more of the students are digital natives - and indeed, as teachers are becoming more digitally savvy - teachers are finding it easier to incorporate new technologies into teaching literature in a foreign language.

\subsection{Integrating language and culture}


We have seen how in many cases writers comment on the division between language departments and literature departments, between language teaching and literature teaching. Reponses to this have been at a variety of levels. Paesani (2005) is an example of response at the lesson level, and presents a lesson plan in which a poem is used to teach the French relative pronouns que and où. Although the poem (by the well known poet Jacques Prévert) which she chooses for this is appropriate for the task, the question that arises is to what extent this is a literature and language lesson, and to what extent this is a language lesson which merely happens to use a literary text. (A similar question arises, for example, from a consideration of lessons in which teachers use poems written by themselves to illustrate specific linguistic phenomena, e.g. Woore 2007).

One strand has been the reciprocal relationship between literature and language awareness. Chan (1999) provides an extensive list of activities that can be used to raise language awareness when teaching a short story. Picken (2005) illustrates the relationship in the opposite direction: raising the awareness of learners to metaphors in order to enable them to recognise invisible metaphors when reading poetry. 
Finally, there are a number of cases where language and literature are integrated in a thoughtful manner through a process of curricular innovation which sometimes encompasses whole departments. One such comprehensive revision of a curriculum is described in Byrnes \& Kord (2002), where Byrnes describes a revision of a four-year German undergraduate curriculum, which takes 'a content-oriented and task-based approach in all courses' (2002:49). This is a fine example of the integration of language and literature teaching, and cross-fertilisation of the two areas in terms of pedagogic approach. Meskill \& Ranglova (2000) illustrate a successful revision of the literature curriculum in Bulgaria. Butler (2006) is an example of the integration of language and literature in a historically black university in South Africa. Lin (2006) is an interesting discussion of the response to the changes in the English language syllabus and the Literature in English syllabus in Singapore. This is taken to the level of approach and of task, with an example of how teaching can respond to and incorporate elements from both syllabuses. Hoecherl-Alden (2006) provides an example of a structured curriculum in which learners begin by reading children's literature, move through young adult literature, and end up reading a contemporary novel. Sell (1995) is an interesting collection of papers in that it documents the way literature is incorporated into foreign language education in one system of education from nursery level through primary, middle, and secondary schooling up to university level. (See also the papers in Brumfit \& Benton 1993 for descriptions of syllabuses from a large number of countries across the world; Parkinson \& Reid-Thomas 2000:160-161 for a brief discussion of syllabuses in the Bulgarian, Malaysian and Cameroonian context; Vethamani 2004 on trends in Malaysia). 
5.5. Extending the contexts and the contents of teaching literature 
The attempt to create a bridge between language courses at the beginning of language study, and literature courses at a later stage has had two consequences. One is the realisation that even at a later stage of language learning, students need linguistic support when reading literature, as well as specific support in using the language of literary argumentation and criticism (Byrnes \& Kord 2002). On the other hand, many teachers and researchers focus on the possibility of using and teaching literature at early stages of language learning. One aspect of this is the use of children's literature with young learners which we have seen above. But other writers have used and taught more complex literature successfully with adult beginners as well (e.g. Lazar 1994, Paesani 2005 and Hoecherl-Alden 2006, which is an example of integrating literature at all levels,)

There is also a clear understanding that literature can be used in a wide variety of learning contexts. The work by Hirvela (2001b, 2005) in EAP contexts is a case in point (see section 6.1.2 below). Bloch (1995), Liaw (2001), and Minkoff (2006) are examples of teaching literature in management situations; Torres (2004) is an example of teaching Spanish in business courses; Viswamohan \& Torche (2007) are examples of using literature in ESP contexts.

Finally, literature is also used as a way of introducing and encouraging critical thinking (Gajdusek \& vanDommelen 1993; Diaz-Santos 2000), and critical literacy (Thompson 2000; Zubair 2003). Kern \& Schultz (2005) provide an example of a curriculum where literature (both whole works and excerpts), films, art, and newspaper articles are used together in the development of critical reading skills. 
5.6. Stylistics and second language learning

One important approach which has been linked to the re-emergence of literature within the context of L2 learning and teaching is stylistics, and many of the important textbooks and teachers' manuals in the last three decades have taken a stylistic approach (e.g. Carter \& Long 1987; Carter \& McRae 1996; McRae 1991/2008; Watson \& Zyngier 2007; Widdowson 1975, 1992). Nevertheless, the relationship between stylistics and L2 learning has not been an easy one; in fact, McRae \& Clark (2004) suggest that 'stylistics has always caused controversy: there are those who deny its usefulness, and those for whom it is an essential branch of applied linguistics' (2004: 328). 
Part of this uneasy relationship is that, although there is a strong element of empirical enquiry within stylistics, this empirical approach has not yet extended to a rigorous examination of classrooms and language learning and even less so to L2 learners. As Hanauer (2001) suggests, stylistics has focused on the analysis of texts, rather than on the process of understanding these texts. Watson \& Zyngier (2007) is a case in point. Of the fifteen chapters in a volume entitled Literature and Stylistics for Language Learners, less than half deal either explicitly or implicitly with L2; the rest either focus on L1 situations, or focus on textual analysis. None of the papers actually tackles the language learning aspect head on; what the reader is then left with is the feeling that language learning issues are assumed to have been resolved, rather than the feeling that these are issues that need to be tackled on an ongoing basis in L2 contexts. Indeed, Clark \& Zyngier (2003) suggest that the aim of activities within a pedagogical stylistics framework is not to achieve an improvement in the learners' linguistic competence, although this may well be a 'by-product of such an activity' (2003: 349). This then probably means that the writers would position themselves in quadrant 3 of Figure 1, where the focus is not on language learning, but rather on literature and on language, or, as they put it, 'on creativity and the multiplicity of meanings produced through patterns of language, rather than the patterns of language themselves, or any consequent accuracy on the part of students in their reproduction' (Clark \& Zyngier 2003: 349). Unfortunately, this can result in a situation where the concerns of stylistics seem remote from the concerns of the language teacher in the classroom. 
This point takes us back to the first confrontation regarding the role of stylistics in language learning, the vitriolic attack by Gower (1986), in which writers arguing for stylistics were accused of writing 'gobbledygook' (p. 127) and 'the spirit of what they've written' was called 'deadly dull (and I mean deadly and dull)” (p. 127). Curiously enough, this has not been responded to in the literature, possibly because of the feeling that it was impossible to interact with such name calling. But although Gower's attack was both vicious and guilty of setting up various false dichotomies (e.g. contrasting stylistic analysis with reader response), it is important to note that it is true, and was even truer at the time, that a great deal of stylistic analysis does not address issues of dealing with the language learner. What is focused on are issues in stylistic analysis, and what seems to be implied is that language issues do not exist. 
There are, however, notable exceptions in which writers who adopt a stylistic approach also deal with issues of language learners. Holst (1989) is an example of a stylistic analysis followed by specific questions and tasks where the linguistic sophistication required is quite clearly within the scope of language learners. Other examples are papers such as Lazar (1990) and Davies (1998), which illustrate a stylistic approach in reading novels in the L2 classroom. Rosenkjar (2006) illustrates a combination of the traditional three-phase reading lesson, in which pre-reading activities ensure that students have the background knowledge and the linguistic knowledge to deal with the poem, with additional activities that focus on an analysis along stylistic lines to illustrate how the poem achieves its meaning. However, such examples are not very common, and many papers in stylistics with L2 learners do not isolate the language issues, and seem to assume that language issues have been dealt with. Thus Crisp (2006), Plummer \& Busse (2006) and Short, Busse \& Plummer (2007) discuss the different manifestations of the same web-based course in stylistics in different contexts, but with minimal attention to the learners as L2 learners. The only discussion of this issue arises in Crisp (2006), where L2 English majors complained that the linguistic knowledge imparted at the beginning of the course was already known to them. In general, clearer evidence needs to be provided that language issues do not arise because they do not present a problem, or whether they do not arise because the research design does not provide a place for them to manifest themselves. 
One important strand in the contribution of stylistics is the way in which it has looked more systematically at language awareness. As Clark \& Zyngier (2003) state, the purpose of the pedagogical stylistics which they advocate is 'to promote linguistically aware readers who can perceive the qualities of language which are manipulated for particular effects (including the aesthetic' (2003: 342). Zyngier, Fialho \& do Prado Rios (2007) move this to the realm of literary awareness, and describe a study which attempted to raise literary and language awareness with EFL learners at a low-intermediate level. The data consisted of journal entries which were then coded for signs of awareness at three levels: absence of awareness, signal of awareness, and presence of awareness. The value of the study is mainly in showing the variations in awareness at different stages of the course, and pointing out the different influences on the level of awareness exhibited.

If stylistics wishes to capture an important place in language learning it will have to address the issues which language teachers and learners are preoccupied with, and will have to demonstrate the usefulness of the approach to language teaching. The type of rigorous attention to task design exemplified in Durant (1996) and Rosenkjar (2006) is an example of best practice and illustrates how pedagogical considerations are often the same whether the objective is to teach language or teach literary analysis; as such, stylistics clearly has much to offer language teachers. However, what we now need is research that will back up the intuitive endorsement of these techniques for language learning; and we do need stylisticians to engage less in conversation among themselves, and more with language teachers. 


\section{Extending the curriculum}

\subsection{General issues}

A general move in literature and language teaching has been a general extension of the curriculum in terms of text types and writers taught. There are, of course, still situations where this has not happened, and where the same writers and works keep being taught. Thus Beck (1995), Hermes (1995) and Nünning (1998) all surveyed their students to find out what they had read in secondary school, and found that there was a small number of works that were read by the vast majority of respondents. But this may only matter if that were the only pieces that the learners were reading. It may be more informative to examine whether in addition to the small number of canonical works that they cite, students have also read or studied other pieces; the variation there might be revealing. This section examines the evidence that teachers are increasingly using a wider variety of works.

6.2 Non-native and minority literatures 
The first moves towards teaching non-native literatures were the calls articulated by Sridhar (1982), Kachru (1986) and Talib (1992), and numerous papers attest to the way in which practitioners have responded to these challenges. Vethamani (1996) discusses the use of works from new literatures in English in a south-east Asian context; McRae (1996) also discusses these issues; Chan (1999) presents as his example the work of a Singaporean writer. Vandrick (1996) discusses the use of multicultural literature in the US context, and surveys a variety of textbooks which include such works in their selection (see also Vandrick 2003). Thompson (2000) used the works of indigenous Australian writers, and Völz (2001) describes the use of works by Terry McMillan written in Black American. This trend is not confined to English: in German, Veteto-Conrad (1997) describes a course focusing on minority literature in German, including Turkish writers and Afro-Germans. In French and Spanish, Burnett \& Fonder-Solano (2002) illustrate the process of moving from a traditional literature course to one 'using as many marginal writers and texts as mainstream works' (2002: 92). 
The motivation in each case varies. Kachru (1986) and Talib (1992) both focus on the use of non-native literature in the context in which it was written: indeed, some of the pedagogic activities which Talib (1992) suggests rely on the students' prior acquaintance with the language variety being used. There is thus a wish to increase the relevance of the literature being taught to the specific context of teaching, through focusing on the local variety of the language. An obvious case in point is Youssef \& Carter (1999), who had Venezuelan EFL students studying in Trinidad \& Tobago perform a play in the Trinidadian dialect. Having said that, many of the cases mentioned above use non-native literatures in contexts different from the context of writing: the aim here is quite simply to exhibit the richness of literatures in English, though always bearing in mind Rönnqvist \& Sell's (1995) caveat - that it is difficult, if not impossible, to achieve any suitably wide representation of English literatures on a language programme.

\subsection{Extending the genres taught}

The opening up of the curriculum includes genre as well. Gordon, Zaleski \& Goodman (2006) include creative non-fiction in the range of genres they discuss; Stewart \& Santiago (2006) describe a Spanish course and an ESL course in which the same piece of autobiographical fiction was used, in the original Spanish, and in an English translation respectively. Other teachers have used a variety of noncanonical genres as well, such as science fiction (Yang 2002), detective fiction (Yang 2001), and technothrillers (Diaz-Santos 2000). 


\subsubsection{Using children's literature}

One major body of literature that is being increasingly used in the language classroom is children's literature and young adult literature. The use of literary texts with children, in particular, illustrates two trends of thought: the broadening of the concept of literature to include nursery rhymes and children's books; and the realisation that in a foreign language, learners might react well to literature that had been written specifically for their own age group. This is well documented in the literature: Martin (2006) describes the ways in which beginning teachers are trained to use children's literature; McNicholls (2006) is a similar description, though in his case this has a dual purpose, and the children's literature is also used as a vehicle for teaching language to the trainees on the programme.

Williams (1995) documents her use of three types of literature with children in a nursery school in Finland: nursery rhymes, fairy tales, and picture books. Indeed, fairy tales are often cited as important because they illustrate the role of literature in the psychological development of the child, providing additional support for the importance of using literature in educational settings (see McNicholls 2006, Davidheiser 2007, Ghosn 2002 for discussion of these issues). 
Children's literature can be used with older L2 learners as well. One example is the teacher training programme described by McNicholls (2006). Another example is Ho (2000), who illustrates how children's literature can be used with adults preparing for university studies in English. Davidheiser (2007) shows how fairy tales can be used at university language courses, illustrating their use in German as a foreign language both at beginners' level and at advanced level. Interestingly, Davidheiser (2007) also shows how fairy tales can be used in an introductory course in which they are taught in the L1

(English). Berg \& Martin-Berg (2002) also discuss the use of fairy tales in the teaching of stylistics in French as a foreign language.

6.3.2 Using Young Adult Literature 
O’Sullivan \& Rösler (2002) include a detailed discussion of the rationale for the use of young adult literature (YAL). Tracing the use of YAL in English, German and French as foreign languages back to the 1920s and 1930s, they survey a large number of courses in which YAL is creatively used to teach language. Rönnqvist \& Sell $(1994,1995)$ articulate the main reasons for using YAL: namely, that teenagers will respond particularly well to literature that is geared towards them in terms of topics, themes, characters and genre.

The case of German as a foreign language is interesting in this respect. A great part of the children's books and YAL discussed in practitioner papers seem to deal with intercultural issues or with cultures in conflict, thus providing an opportunity to raise these issues in the classroom. Moffitt (1998) describes a project dealing with a novel about a young Turkish girl in Germany; Schulz (1998) deals with a YAL novel about the Holocaust; Metcalf (1998) chose children's books about WWII and the post-war years; Dollenmayer \& Even (2005) describe a course using a novel whose protagonists are an Irish girl and a German boy, and which employs a bilingual writing technique. It is hard to know, however, whether this focus on intercultural issues represents the choices that the language teachers made, or whether this is a general phenomenon in German YAL literature.

\section{Conclusion and future research directions}


This paper has considered the research into the use of literature in L2 settings. I have demonstrated that principled evidence is emerging that is showing the benefits of using literature, and we are now in a better position to refute the claims made, for example by Edmondson (1997). There are, of course, still various points which still need to be addressed. It goes without saying that more research is needed in all of the areas discussed in this paper. Although I have made a case in support of practitioner evidence, we still need more empirical studies into what happens in literature and language classrooms, along the lines of the papers discussed in section 3, as well as what happens when individuals read literature in their L2, along the lines of the investigation described by Hanauer (2001). We also need more systematic evaluation of courses, and systematic enquiries into the views of the learners. We also need to investigate issues of testing in the language and literature classroom (Paran, forthcoming). On a more general level, there is a sense in which more recent views of literature as discourse have not yet impacted on the L2 classroom, and this impact will also need to be researched (see Hall 2005 for an in-depth exposition of this area, as well as for an extensive discussion of possible research projects). Other areas were not discussed in this paper at all: the role of literature in a foreign language in supporting inter-cultural competence (for an overview see Bredella 2000b), or the role of creative writing in L2 learning (see for example, Ensslin 2006; Spiro, forthcoming). An overview that would encompass those would go a long way towards transforming the possibly simplistic Figure 1 in this survey to a more extensive model of the ways in which literature can be used in L2 learning and teaching. 
Possibly the most important point to observe - and it is important because this is not immediately apparent - is that most of the detailed empirical studies discussed in this paper were conducted almost entirely in university settings. This bias towards university teaching is probably an artefact of the difficulties that researchers are facing in researching secondary school settings: academics will normally have better access to university students than to secondary schools; research in secondary schools may often require parental consent. School settings are represented in this paper mainly through practitioner evidence. We thus need two types of information. One is survey research that will demonstrate the extent of the use of literature in the L2 classroom in primary and secondary school settings. We then need is research into the way literature is taught in these setting, how it is perceived by teachers and received by students, how successful it is in promoting language proficiency. These school settings, are, after all, the locus of most language learning in the world, and there are important aspects of this learning (and teaching) that are still unexplored. 
It is clear that literature does have something very special to offer to language learning. As Hanauer (1997) has argued, it combines attention to meaning with attention to form. We have evidence that it is motivating and engaging, and, in the cases where learners show resistance and dislike of literature, we understand why it is the case. We understand its value for the learner, and we are also beginning to understand the importance of the learning task that is provided by the teacher for the success of language learning in this context and for the success of literary understanding as well. Clearly, providing adequate direction and clear scaffolding is vital. This scaffolding may be provided by a textbook or a reader, but more often than not, it is provided by the teacher, who is important in two ways. One is the way in which the task is set up; the second is the way in which a teacher can react to the way a discussion is going, provide scaffolding as and when it is needed. Overall, we are also beginning to understand the role of the teacher in this area, providing us with the beginnings of an understanding of how to go about training teachers who will be competent and confident in confronting the issues involved in using literature in the language classroom. 


\section{References}

Ali, S. (1993). The reader-response approach: An alternative for teaching literature in a second language. Journal of Reading 37.4, 288-296.

Badran, D. (2007). Stylistics and language teaching: Deviant collocation in literature as a tool for vocabulary expansion. In M. Lambrou \& P. Stockwell (eds.), Contemporary stylistics, London \& New York: Continuum. 180-192.

Baurain, B. (2007). Small group multitasking in literature classes. ELT Journal 61.3, $237-245$.

Beatty, K. \& D. Nunan (2004). Computer-mediated collaborative learning. System $32.2,165-183$.

Beck, R. (1995). Macbeth, Animal Farm und kein Ende! Was haben Studienanfänger in der Anglistik gelesen? Neusprachliche Mitteilungen, 48, 31-38.

Belcher, D. \& A. Hirvela (2000). Literature and L2 composition: Revisiting the debate. Journal of Second Language Writing 9.1, 21-39.

Benton, M. (1996). The discipline of literary response: approaches to poetry with L2 students. In Bredella \& Delanoy (eds.), 30-44.

Berg, W. \& L.K. Martin-Berg (2002). A stylistic approach to foreign language acquisition and literary analysis. In Scott \& Tucker (eds.), 173-191.

Bernhardt, E.B. (2002). Research into the teaching of literature in a second language: what it says and how to communicate it to graduate students. In Scott \& Tucker (eds.), 195-210.

Bloch, B. (1995). Using literature to teach cross-cultural management: A German perspective. Die Unterrichtspraxis 28.2, 146-152. 
Bloom, B.S. (1956). Taxonomy of educational objectives: The classification of educational goals. Handbook 1, Cognitive domain. New York: McKay.

Boyd, M. \& V. M. Maloof (2000). How teachers can build on student-proposed intertextual links to facilitate student talk in the ESL classroom. In J. K. Hall \& L. S. Verplaetse (eds.), Second and foreign language learning through classroom interaction. Mahwah, NJ: Erlbaum, 163-182.

Bredella, L. (2000a). Literary texts. In Byram (ed.) (2000), 375-382.

Bredella, L. (2000b). Literary texts and intercultural understanding. In Byram (ed.) (2000), 382-386.

Bredella, L. \& W. Delanoy (eds.) (1996). Challenges of literary texts in the foreign language classroom. Tübingen: Gunter Narr.

Browner, S., S. Pulsford \& R. Sears (2000). Literature and the internet. A guide for students, teachers and scholars. New York, NY: Garland Publishing.

Brumfit, C. \& M. Benton (1993). Teaching literature: A world perspective. Modern English Publications and the British Council. Basingstoke: Macmillan.

Burnett, J. \& L. Fonder-Solano (2002). Crossing the boundaries between literature and pedagogy: Perspectives on a foreign language reading course. In Scott \& Tucker (eds.), 75-106.

Butler, I. (2006). A brighter future? Integrating language and literature for first-year university students. In Paran (ed.), 11-25.

Byram, M. (ed.) (2000). Routledge encyclopaedia of language teaching and learning. London and New York: Routledge.

Byrnes, H. \& S. Kord (2002). Developing literacy and literary competence: 
Challenges for foreign language departments. In Scott \& Tucker (eds.), 35-73.

Carter, R. (2007). Literature and language teaching 1986 - 2006: A review. International Journal of Applied Linguistics 17.1, 3-13.

Carter, R. \& M. N. Long (1987). The web of words: exploring literature through language. Cambridge: CUP.

Carter, R. \& J. McRae (eds.) (1996). Language, literature and the learner. Harlow: Addison Wesley Longman Ltd.

Carter, R. \& D. Nunan (eds.) (2000). The Cambridge guide to teaching English to speakers of other languages. Cambridge: Cambridge University Press.

Celce-Murcia, M. (ed.) (2001). Teaching English as a second or foreign language (3 $3^{\text {rd }}$ edn.). Boston: Heinle \& Heinle.

Chan, P. K. W. (1999). Literature, language awareness and EFL. Language Awareness 8.1, 38-50.

Clark, U. \& S. Zyngier (2003). Towards a pedagogical stylistics. Language and Literature 12.4, 339-351.

Cranston, M. (2003). Rhyme or reason? The teaching of poetry in the foreign language classroom. The French Review 76.5, 954-966.

Crisp, P. (2006). E-learning and Language and Style in Hong Kong. Language and Literature 277-290.

Davidheiser, J. C. (2007). Fairy tales and foreign languages: Ever the twain shall meet. Foreign Language Annals 40.2, 215-225.

Davies, D. (1998). Metadiscourse and the evasive narrator: A process-based approach to teaching Ishiguro's The Remains of the Day. Reading in a Foreign Language 
$12.1,271-279$.

Davis, J. N., L. Carbón Gorell, R. R. Kline \& G. Hsieh (1992). Readers and foreign languages: A survey of undergraduate attitudes toward the study of literature. The Modern Language Journal 76.3, 320-332.

Delanoy, W. (1996). The complexity of literature teaching in the language classroom: A reflective practitioner's view. In Bredella \& Delanoy (eds.), 62-90.

Diaz-Santos, G. (2000). Technothrillers and English for science and technology. English for Specific Purposes 19.3, 221-236.

Dollenmayer, D. \& S. Even. (2005). Mensch, be careful! Bilinguale Jugendliteratur für fortgeschrittene Anfänger. Die Unterrichtspraxis 38.1, 9-18.

Donato, R. \& F. B. Brooks (2004). Literary discussions and advanced speaking functions: Researching the (dis)connection. Foreign Language Annals, 37.2, 183199.

Durant, A. (1996). Designing groupwork activities: A case study. In Carter \& McRae (eds.), 65-88.

Edmondson, W.(1997). The role of literature in foreign language learning and teaching: Some valid assumptions and invalid arguments. In A Mauranen. \& K. Sajavaara (eds.), Applied linguistics across disciplines. AILA Review No. 12 1995/6. 42-55.

Ensslin, A. (2006). Literary hypertext in the foreign language classroom: A case study report. Language Learning Journal 33, 13-21.

Fecteau, M. L. (1999). First- and second-language reading comprehension of literary texts. The Modern Language Journal 83.4, 475-493. 
Fonder-Solano, L. \& J. Burnett (2004). Teaching literature/reading: A dialogue on professional growth. Foreign Language Annals 37.3, 459-467.

Fraser, C. C. (1999). Goethe gossips with Grass: Using computer chatting software in an introductory literature course. Die Unterrichtspraxis 32.1, 65-74.

Gajdusek, L. \& D. vanDommelen (1993). Literature and critical thinking in the composition classroom. In J. G. Carson \& I. Leki (eds.), Reading in the composition classroom: Second language perspectives. Boston, MA: Heinle \& Heinle, 197-217.

Ghosn, I.K. (2002). Four good reasons to use literature in primary school ELT. ELT Journal 56.2, 172-179.

Gilroy, M. (1995). An investigation into teachers' attitudes to using literature in the language classroom. Edinburgh Working Papers in Applied Linguistics 6, 1-17.

Gilroy, M. \& B. Parkinson (1996). State of the art article: Teaching literature in a foreign language. Language Teaching 29.4, 213-225.

Givens, C. F. (1976). A descriptive study of the cognitive level of classroom discourse of college professors and students. Unplublished dissertation. Claremont Graduate University. Claremont, CA.

Gombocz, I. (2001). Mephistopheles live: Teaching German literature via distance learning. Die Unterrichtspraxis 34.1, 60-65.

Gordon, T., J. Zaleski \& D. Goodman. (2006). Stories lean on stories: Literature experiences in ESL teacher education. In Paran (ed.), 59-70.

Gower, R. (1986). Can stylistic analysis help the EFL learner to read literature? ELT Journal 40.2, 125-130. 
Hall, G. (2005). Literature in language education. Basingstoke: Palgrave Macmillan.

Hanauer, D. (1997). Poetry reading in the second language classroom. Language Awareness 6: 1-15.

Hanauer, D. (2001). The task of poetry reading and second language learning. Applied Linguistics 22.3, 295-323.

Hanauer, D. (2007). Attention-directed literary education: an empirical investigation. In Watson \& Zyngier (eds.), 169-180.

Harlow, L. L. \& J. M. Muyskens (1994). Priorities for intermediate-level language instruction. The Modern Language Journal, 78.2, 141-154.

Harmer, J. (2001). The practice of English language teaching. ( ${ }^{\mathrm{rd}}$ edn.). Harlow: Pearson Education.

Hedge, T. (2000). Teaching and learning in the language classroom. Oxford: Oxford University Press.

Hermes, L. (1995). Learning logs als Instrument der Selbstkontrolle und als Evaluation in literaturwissenschaftliche Proseminaren. In W. Börner \& K. Vogel (eds.), Der Text im Fremdsprachunterricht, Bochum: AKS Verlag, 85-98.

Hess, N. (2003). Real language through poetry: a formula for meaning making. ELT Journal 57.1, 19-25.

Hess, N. (2006). The short story: Integrating language skills through the parallel life approach. In Paran (ed.), 27-43.

Hirvela, A. (1989). Five bad reasons why language teachers avoid literature. British Journal of Language Teaching 27.3, 127-132.

Hirvela, A. (2001a). Connecting reading and writing through literature. In D. Belcher 
\& A. Hirvela (eds.), Linking Literacies: Perspectives on L2 reading-writing connections. Ann Arbor, MI: University of Michigan Press, 109-134.

Hirvela, A. (2001b). Incorporating reading into EAP writing courses. In J. Flowerdew \& M. Peacock (eds). Research perspectives on English for academic purposes. Cambridge: CUP, 330-346.

Hirvela, A. (2005). ESL students and the use of literature in composition courses. Teaching English in the Two-Year College 33.1, 70-77.

Hirvela, A. (2007). Computer-mediated communication and the linking of students, text, and author on an ESL writing course listserv. Computers and Composition, 24, 3-55.

Ho, L. (2000). Children's literature in adult education. Children's Literature in Education 31.4, 259-271.

Hoecherl-Alden, G. (2006). Connecting language to content: second language literature instruction at the intermediate level. Foreign Language Annals 39.2, $244-254$.

Holst, J. (1989). Foregrounding in 'The Wasteland': a stylistics approach. In R. Carter, R. Walker \& C. Brumfit (eds.), Literature and the learner: Methodological approaches. Modern English Publications with the British Council, 39-46.

Horowitz, D. (1990). Fiction and nonfiction in the ESL/EFL classroom: Does the difference make a difference? English for Specific Purposes 9.2, 161-168.

Isaac, A. (2002). 'Opening Up' literary cloze. Language and Education 16.1, 18-36. Jackstädt, H. \& A. Müller-Hartmann (2001). Encounters: The virtual in search of the 
intercultural. In J. Edge (ed.), Action research. Alexandria, VA: TESOL, 117128.

Kachru, B. B. (1986). Non-native literatures in English as a resource for language teaching. In C.J. Brumfit \& R.A. Carter (eds.) Literature and language teaching. Oxford: OUP, $140-149$.

Kelly, R. K. \& L. A. Krishnan (1995). "Fiction talk" in the ESP classroom. English for Specific Purposes. 14.1, 77-86.

Kern, R. \& J. M. Schultz (2005). Beyond orality: Investigating literacy and the literary in second and foreign language instruction. The Modern Language Journal 89.3, 381-392.

Kim, M. (2004). Literature discussions in adult L2 learning. Language and Education $18.2,145-166$.

King, L. J. (2000). Teaching German literature through the web: Processes and outcomes. Die Unterrichtspraxis 33.1, 61-70.

Kormos, J., E. H. Kontra, \& A. Csölle (2002). Language wants of English majors in a non-native context. System 30.4, 517-542.

Kramsch, C. (1993) Context and culture in language teaching. Oxford: Oxford University Press.

Kramsch, C. \& O. Kramsch (2000). The avatars of literature in language study. The Modern Language Journal 84.1, 553-573.

Kramsch, C. \& T. Nolden (1994). Redefining literacy in a foreign language. Die Unterrichtspraxis 27.1, 28-35.

Lao, C. Y. \& S. Krashen (2000). The impact of popular literature study on literacy 
development in EFL: More evidence for the power of reading. System, 28.2, 261270.

Lazar, G. (1990). Using novels in the language-learning classroom. ELT Journal $44.3,204-214$.

Lazar, G. (1994). Using literature at lower levels. ELT Journal, 48.2, 115-124.

Liaw, M-L. (2001). Exploring literary responses in an EFL classroom. Foreign Language Annals 34.1, 35-45.

Lin, B. (2006). Exploring the literary text through grammar and the (re-)integration of literature and language teaching. In Paran (ed.), 101-116.

Lott, B. (1988) State of the art article: Language and literature. Language Teaching $21.1,1-13$.

Louw, B. (1997). The role of corpora in critical literary appreciation. In A. Wichmann, S. Fligelstone, T. McEnery, \& G. Knowles (eds.). Teaching and Language Corpora. London: Longman, 240-251.

Lyman-Hager, M. A. (2000). Bridging the language-literature gap: Introducing literature electronically to the undergraduate language student. CALICO Journal $17.3,431-452$.

Mackay, R. (1992). Lexicide and goblin-spotting in the language/literature classroom. ELT Journal 46.2, 199-208.

Mantero, M. (2002). Bridging the gap: Discourse in text-based foreign language classrooms. Foreign Language Annals 35.4, 437-455.

Martin, I. (2006). Terms of integration: Educating primary EFL teacher learners. In Paran (ed.), 87-100. 
Martin, A. M. \& I. Laurie (1993). Student views about the contribution of literary and cultural content to language learning at intermediate level. Foreign Language Annals 26.2, 189-207.

Mattix, M. (2002). The pleasure of poetry reading and second language learning: A response to David Hanauer. Applied Linguistics 23.4, 515-518

McNicholls, S. (2006). Using enchantment: Children's literature in an EFL teacher education context. In Paran (ed.), 71-85.

McRae, J. (1991/2008). Literature with a small 'l'. Basingstoke: Macmillan/Nottingham: CCCP Press.

McRae, J. (1996). Dances with thorns: Perspectives on the teaching of new literatures. In Bredella \& Delanoy (eds.), 227-232.

McRae, J. \& U. Clark (2004). Sylistics. In A. Davies \& C. Elder (eds.), The Handbook of Applied Linguistics. Oxford: Blackwell Publishing. pp. 328-346.

Meskill, C. \& K. Ranglova (2000). Sociocollaborative language learning in Bulgaria. In M. Warschauer \& R. Kern (eds.) Network-based language teaching: concepts and practice. Cambridge: Cambridge University Press, 20-40.

Metcalf, E-M. (1998). Children's and young adult books in the intermediate and advanced German class: two projects. Die Unterrichtspraxis 31.2, 148-153.

Minkoff, P. (2006). Talking it over in class. In Paran (ed.), 45-57.

Moffit, G. (1998) Oya? - O, ja! Reading Jugendliteratur in the German classroom. Die Unterrichtspraxis, 31.2, 116-124.

Murti, K. P. (1996). Teaching literature at the first-year graduate level: The quantum leap from language to literature. In Bredella \& Delanoy (eds.), 185-204. 
Nünning, A. (1998). Von "teaching drama" zu "teaching plays". Der Fremdsprachliche Unterricht Englisch, 27.1, 5-13.

O’Sullivan, E. \& D. Rösler (2002). Fremdsprachenlernen und Kinder- und Jugendliteratur: Eine kritische Bestandaufname. Zeitschrift für Fremdsprachenforschung 13.1, 63-111.

Paesani, K. (2005). Literary texts and grammar instruction: Revisiting the inductive presentation. Foreign Language Annals 38.1, 15-24.

Paran, A. (1999). Methodological issues in using poetry in the ELT classroom. ELT News and Views: Literature in ELT Supplement 6.1, 20-22.

Paran, A. (ed.) (2006a). Literature in Language Teaching and Learning. Alexandria, VA: TESOL.

Paran, A. (2006b). The stories of literature in language learning. In Paran (ed.), 1-10.

Paran, A. (forthcoming). Between Scylla and Charybdis: The dilemmas of testing language and literature. In Paran \& Sercu (eds.).

Paran, A. \& L. Sercu (eds.) (forthcoming). Testing the untestable in language teaching. Clevedon: Multilingual Matters.

Picken, J. D. (2005). Helping foreign language learners to make sense of literature with metaphor awareness-raising. Language Awareness, 14.2\&3, 142-152.

Parkinson, B. \& H. Reid-Thomas. (2000). Teaching literature in a second language. Edinburgh: Edinburgh University Press.

Plummer, P. \& B. Busse (2006). E-learning and Language and Style in Mainz and Münster. Language and Literature 15.3, 257-276.

Qiping, Y. \& C. Shubo. (2002). Teaching English literature in China: Importance, 
problems, and countermeasures. World Englishes 21.2, 317-324.

Richards, J.C. \& W. A. Renandya (eds.) (2002). Methodology in Language Teaching: An Anothology of Current Practice. Cambridge: Cambridge University Press.

Rönnqvist, L. \& R. D. Sell (1994). Teenage books for teenagers: Reflections on literature in language education. ELT Journal 48.2, 125-132.

Rönnqvist, L. \& R. D. Sell (1995). Teenage books in foreign-language education for the middle school. In Sell (ed.), 40-73.

Rosenblatt, L. M. (1978). The reader, the text, the poem. Carbondale: Southern Illinois University Press.

Rosenkjar, P. (2006). Learning and Teaching How a Poem Means: Literary Stylistics for EFL Undergraduates and Language Teachers in Japan. In Paran (ed.), 117131.

Schaumann, C. (2001). Erzählraum im virtuellen Raum: Rewriting Bernhard Schlink's Der Vorleser on the Web. Die Unterrichtspraxis 34.2, 150-157.

Schmidt, I. 2004. Methodische Vorgehenswesen und Schüllerinteresse: Bericht über ein empirisches Forschungprojekt. In I. Schabert (hrsg.) Shakespeare Jahrbuch Band 140/2004, Bochum: Verlag und Druckkontor Kamp Gmbh, 196-211.

Schulte, F. (2006). Collaborative producing of digital learning objects for language and literature instruction in the Netherlands. In Paran (ed.), 161-173.

Schulz, R. A. (1998). Using young adult literature in content-based German instruction: teaching the Holocaust. Die Unterrichtspraxis 31.2, 138-147.

Scott, V. M. (2001). An applied linguist in the literature classroom. The French Review, 74.3, 538-549. 
Scott, V. M. \& J. A. Huntington (2007). Literature, the interpretive mode, and novice learners. The Modern Language Journal 91.1, 3-14.

Scott, V. M. \& H. Tucker (eds.) (2002). SLA and the literature classroom: Fostering dialogues. Boston, MA: Heinle and Heinle.

Sell, R. D. (ed.) (1995). Literature throughout foreign language education: The implications of pragmatics. Modern English Language Publications in Association with the British Council.

Shanahan, D. (1997). Articulating the relationship between language, literature and culture: Toward a new agenda for foreign language teaching and research. Modern Language Journal 81.2, 164-174.

Short, M., B. Busse \& P. Plummer (2007). Investigating student reactions to a webbased stylistics courses in different national and educational settings. In Watson \& Zyngier (eds.), 106-125.

Spiro, J. (forthcoming). Crossing the bridge from appreciative reader to reflective writer: The assessment of creative process. In Paran \& Sercu (eds.).

Sridhar, S. (1982). Non-native English literature: Context and relevance. In B. Kachru (ed.) The other tongue: English across cultures. Urbana, IL: University of Illinois Press, 291-306.

Standards for foreign language learning: Preparing for the 21 $1^{\text {st }}$ century. (1996/1999). New York: ACTFL and the National Standards in Foreign Language Education Project.

Stewart, J. A. \& K. A. Santiago (2006). Using the literary text to engage language learners in a multilingual community. Foreign Language Annals 39.4, 683-696. 
Talib, I. S. (1992). Why not teach non-native English literature? ELT Journal 46.1, 51-55.

Thompson, C. (2000). Critical literacy and text selection in English for academic purposes courses. Prospect 15.2, 39-47.

Torres, G. (2004). Practical ways to integrate literature into Spanish for international business courses. Foreign Language Annals 37.4, 584-590.

Tucker, R. (2000). Mallarmé's “Le vierge, le vivace et le bel aujourd'hui” for firstsemester French students or who decreed only Prévert for first year? The French Review 74.2, 263-273.

Tutas, N. (2006). Theory into practice: teaching and responding to literature aesthetically. In Paran (ed.), 133-145.

Ur, P. (1996). A course in language teaching. Cambridge: Cambridge University Press.

Vandrick, S. (1996). Issues in using multicultural literature in college ESL writing classes. Journal of Second Language Writing, 5.3, 253-269.

Vandrick, S. (2003). Literature in the teaching of second language composition. In B. Kroll (ed.), Exploring the dynamics of second language writing. Cambridge: Cambridge University Press, 263-283.

Veteto-Conrad, M. (1997). “deutsche Sprache, gute Sprache...” Minorities in Germany and their German-language literature for upper-division German. Die Unterrichtspraxis 30.1, 59-67.

Vethamani, M. E. (1996). Common ground: incorporating new literatures in English in language and literature teaching. In Carter \& McRae (eds.), 204-216. 
Vethamani, M. E. (2004). Changing tides: teaching literature in English in Malaysian secondary schools. In M. K. David (ed.), Teaching of English in second and foreign language settings: Focus on Malaysia. Frankfurt: Peter Lang, 52-58.

Viswamohan, A. \& U. Torche. (2007). Literature and media in an ESP classroom. In Beaven, B. (ed.), IATEFL 2006 Harrogate conference selections. Canterbury: IATEFL, 104-105.

Völz, S. (2001). Teaching Terry McMillan's short fiction. ELT Journal 55.2, 164171.

Watson, G. \& S. Zyngier (eds.) (2007). Literature and stylistics for language learners. Theory and practice. Basingstoke and New York: Palgrave Macmillan.

Weist, V. D. (2004). Literature in lower-level courses: making progress in both language and reading skills. Foreign Language Annals 37.2, 209-221.

Weston, A. (1996). Picking holes: Cloze procedures in prose. In Carter \& McRae (eds.), 115-137.

Widdowson, H. (1975). Stylistics and the teaching of literature. London: Longman.

Widdowson, H. (1992). Practical stylistics. Oxford: Oxford University Press.

Wilkins, D. (1976). Notional Syllabuses. Oxford: Oxford University Press.

Williams, L. (1995). Literature-based activities in a foreign-language nursery school. In Sell (ed.), 21-35.

Woore, R. (2007). 'Weisse Maus in meinem Haus': using poems and learner strategies to help learners decode the sounds of the L2. Language Learning Journal 35.2, 175-188.

Yang, A. (2001). Reading and the non-academic learner: a mystery solved. System 
29.4, 450-460.

Yang, A. (2002). Science fiction in the EFL class. Language, Culture and Curriculum 5.1, 50-60.

Yeh, A. (2005). Poetry from the heart. English Today 21.1, 45-51.

Youssef, V. \& B-A. Carter (1999). Confronting local dialect and culture issues in the EFL classroom. Language, Culture \& Curriculum 12.1, 31-41.

Zubair, S. (2003). Women's critical literacy in a Pakistani classroom. Changing English 10.2, 163-173.

Zyngier, S., O. Fialho \& P. A. do Prado Rios (2007). Revisiting literary awareness. In Watson \& Zyngier (eds.), 194-209. 